Ks. Paweł Wygralak ${ }^{1}$

\title{
Duch Święty w nauczaniu św. Ildefonsa z Toledo
}

\section{Wprowadzenie}

Ildefons z Toledo podejmuje temat Ducha Świętego we wszystkich zachowanych dziełach teologicznych. Najwięcej miejsca poświęca $\mathrm{Mu}$ i najszerzej o Nim poucza w traktacie De cognitione baptismi w części, w której wyjaśnia treści Składu Apostolskiego. Do tego tematu powraca także w De itinere deserti ${ }^{2}$ oraz w dziele De virginitate Sanctae Mariae, koncentrując się tu jednak przede wszystkim na roli Ducha Świętego w akcie wcielenia Bożego Syna. W swojej nauce o trzeciej osobie Trójcy Przenajświętszej Ildefons kontynuuje nauczanie wcześniejszych ojców, opierając się przede wszystkim na przemyśleniach Augustyna z Hippony oraz Izydora z Sewilli³ . Na podstawie analizy treści wspomnianych wyżej dzieł biskupa Toledo omówimy jego studium na temat natury Ducha

\footnotetext{
1 Ks. prof. UAM dr hab. Paweł Wygralak, dziekan Wydziału Teologicznego Uniwersytetu im. Adama Mickiewicza w Poznaniu; e-mail: pawelwyg@amu.edu.pl; ORCID: 0000-0001-7790-7864.

2 Dzieła De cognitione baptismi i De itinere deserti stanowią według V. Yarza Urquiola dwie części jednego traktatu poświęconego sakramentowi chrztu świętego. Por. V. Yarza Urquiola, Introdución y estudio, w: Ildefonsi Toletani Episcopi, De virginitate Sanctae Mariae, De cognitione baptismi, De itinere deserti, CCL 114 A, Turnhout 2007, s. 277.

3 Por. J.M. Hormaeche Basauri, La pastoral de la iniciación cristiana en la España visigoda: estudio sobre „De cognitione baptismi” de San Ildefons de Toledo, Toledo 1983, s. 98.
} 
Świętego i Jego relacji do Ojca i Syna, dalej przedstawimy Jego rolę w dziele zbawienia, by w ostatniej części ukazać funkcję, jaką pełni w życiu ucznia Jezusa Chrystusa. Warto zauważyć, że temu zagadnieniu Ildefons poświęca najwięcej miejsca w swoich chrzcielnych wskazaniach, które skierowane są przede wszystkim do duchowieństwa, a więc biskupów, opatów i prezbiterów. Dzięki temu nauczanie biskupa Toledo jest w swojej formie oryginalne $e^{4}$.

\section{Natura Ducha Świętego}

Ildefons z Toledo wyznaje wiarę w bóstwo Ducha Świętego ${ }^{5}$ oraz Jego równość z Ojcem i Synem, a także pochodzenie od Ojca i Syna. W De cognitione baptismi stwierdza jednoznacznie: „Bóg jest Ojcem i Synem, i Duchem Świętym. Ojciec nie pochodzi od nikogo, lecz z siebie i jest tylko Ojcem. Syn jest zrodzony z Ojca i stąd z Nim jest współwieczny, i jest tylko Synem. Duch Święty niepodzielnie pochodzi od Ojca i Syna, i jest tylko Duchem Świętym. Cała Trójca jest przeto jednym Bogiem".

W tym krótkim wyznaniu wiary biskup Toledo stara się wyjaśnić w sposób syntetyczny, ale i niebudzący żadnych wątpliwości, prawdę o bóstwie Syna, który jest współwieczny z Ojcem (coaeternus Patri), jak i o bóstwie Ducha Świętego, który pochodzi od Ojca i Syna (Spiritus Sanctus ex Patre et Filio inseprabiliter procedit). Należy pamiętać, że prawda o pochodzeniu Ducha Świętego od Ojca i Syna została w Hiszpanii

4 Por. M.C. Díaz y Díaz, La obra literaria de los obispos visigóticos toledanos: Supuestos y circunstancias, en: La patrología toledano-visigoda, XXVII Semana Española de Teología (Toledo, sept. 1967), Madrid 1970, s. 55-56; V. Yarza Urquiola, Introducción, w: Ildefonsi Toletani Episcopi, De virginitate Sanctae Mariae, De cognitione baptismi, De itinere deserti, CCL 114 A, Turnhout 2007, s. 282.

5 Por. Ildefonsus Toletanus, De cognitione baptismi LXIV.

6 Ildefonsus Toletanus, De cognitione baptismi III, CCL 114 A, s. 354, tł. A. Strzelecka, Ildefons z Toledo, Pouczenie o chrzcie, POK 33, Poznań 2018, s. 39. 
już nie tylko powszechnie przyjęta, ale także wprowadzona do liturgii ${ }^{7}$. Stwierdza więc Ildefons, że „Cała Trójca jest jednym Bogiem”, który jest „niewidzialny, niepojęty, nie dający się oszacować, jest nieśmiertel-

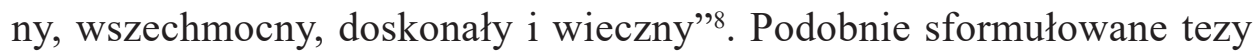
na temat osób Trójcy Świętej przedstawił wcześniej św. Augustyn, aczkolwiek uczynił to w znacznie szerszym wywodzie, podkreślając także równość osób Bożych w ich przymiotach wiekuistości i niezmienności ${ }^{9}$.

Prawdę o pochodzeniu Ducha Świętego od Ojca i Syna biskup Toledo stara się omówić szerzej. Stwierdza więc, że skoro Ojciec jest Bogiem, to pochodzący od Niego z całą pewnością jest również Bogiem ${ }^{10}$. Jego zdaniem użyty termin ,pochodzący” (łac. procedens) zapobiega popełnieniu błędów teologicznych. Nie można mówić o Nim, że jest zrodzony, gdyż sugerowałoby to, że w Trójcy Świętej są dwaj zrodzeni. Nie można też użyć terminu „niezrodzony”, gdyż to mogłoby sugerować, że w Trójcy Świętej są dwaj ojcowie. Zatem określeniem najlepiej oddającym prawdę o relacji Ducha Świętego do Ojca i Syna jest słowo „pochodzący”. Zdaniem Ildefonsa wyraz ten ma źródło w wypowiedzi Chrystusa skierowanej do Apostołów: „Jeszcze wiele mam wam do powiedzenia, lecz teraz nie możecie tego pojaćc. Przyjdzie Duch Prawdy, który od Ojca pochodzi i z mojego weźmie. On wam wszystko objawi” (J 16,12-13) $)^{11}$.

Mówiąc o świętości Ducha Świętego, biskup Toledo powołuje się na świętość Ojca i Syna. Zatem skoro Ojciec i Syn są święci, to również pochodzący od Nich Duch musi być święty. Jest więc wspólna świętość wszystkich osób Trójcy Świętej ${ }^{12}$. Ildefons podkreśla także

\footnotetext{
Filioque zostało włączone do Credo na trzecim synodzie w Toledo w 589 roku.

Ildefonsus Toletanus, De cognitione baptismi III, CCL 114 A, s. 354, POK 33, s. 39.

9 Por. Augustinus Hipponensis, De doctrina christiana I 5, 5.

10 Por. Ildefonsus Toletanus, De cognitione baptismi LV.

11 Por. Ildefonsus Toletanus, De cognitione baptismi LVIII. Por. także: F. Huidobro,
} San Ildefonso de Toledo, „Teología y Vida” 23 (1982) s. 197.

12 Por. Ildefonsus Toletanus, De cognitione baptismi LVII. 
prawdę, że Duch Święty pełni w Trójcy Świętej funkcję jednoczącą, a czyni to jako miłość ${ }^{13}$.

W swoich rozważaniach o Duchu Świętym Ildefons podejmuje jeszcze temat określeń Ducha Świętego. Jest On nazywany „tchnieniem”, gdyż stanowi tchnienie Ojca i Syna. Jego imieniem własnym natomiast jest termin „duch” (spiritus). Jednak duchem jest również Ojciec i Syn, a także, zgodnie z przekazem Pisma Świętego, wszelka bezcielesna natu$\mathrm{ra}^{14}$. Duch Święty jest nazwany w Piśmie Świętym także „Palcem Bożym”. Imię to Ildefons przyznaje trzeciej osobie Trójcy Przenajświętszej na podstawie połączenia dwóch wypowiedzi Chrystusa: „Palcem Bożym wyrzucam złe duchy” (Łk 11,20) i „Mocą Ducha Bożego wyrzucam złe duchy” (Mt 12,28). W ten sposób, nazywając Ducha Świętego „Palcem Bożym”, zostaje podkreślona jego sprawcza moc, wspólna z Ojcem i Synem, która - zgodnie z myślą św. Pawła - udziela się każdemu tak, jak chce.

W swoich rozważaniach o tajemnicy Trójcy Świętej biskup Toledo daje się poznać jako człowiek głębokiej wiary i jednocześnie teologicznej pokory. Stwierdza bowiem, że o naturze boskiej osób Trójcy Świętej nie może wiele powiedzieć, gdyż dla człowieka pozostaje ona tajemnicą ${ }^{15}$.

\section{Rola Ducha Świętego w dziele zbawienia}

Duch Święty uczestniczy we wszystkich dziełach Bożych, począwszy od aktu stworzenia ${ }^{16}$. Ildefons podkreśla: „Cała Trójca, jeden Bóg, uczyniła wszystkie rzeczy widzialne i niewidzialne" ${ }^{17}$. Ale to Duch Święty przez proroków zapowiadał przyjście Zbawiciela ${ }^{18}$. Jego szczególne

\footnotetext{
13 Por. Ildefonsus Toletanus, De cognitione baptismi LXV.

14 Por. Ildefonsus Toletanus, De cognitione baptismi LVI; LXIII.

15 Por. Ildefonsus Toletanus, De cognitione baptismi XCVI.

16 Por. Ildefonsus Toletanus, De cognitione baptismi CXII.

17 Ildefonsus Toletanus, De cognitione baptismi IV, CCL 114 A, s. 355, POK 33, s. 40.

18 Por. Ildefonsus Toletanus, De virginitate Sanctae Mariae 227, 280.
} 
działanie uwidacznia się w tajemnicy poczęcia Bożego Syna. Tematowi temu biskup Toledo poświęca wiele miejsca w swoich rozważaniach, wychodząc od prawdy wypowiadanej w Credo: „Który narodził się z Ducha Świętego i Maryi Dziewicy"19. Zastanawiające według niego jest stwierdzenie, że Jezus Chrystus narodził się z Maryi i z Ducha Świętego. Z całą pewnością chodzi tu o poczęcie Zbawiciela z substancji boskiej i ludzkiej. W ten sposób Ildefons podkreśla prawdę o dwóch pełnych naturach w Chrystusie. Biskup Toledo wraca jednak do pytania o znaczenie faktu, że Jezus narodził się z Ducha Świętego: „Z Ducha Świętego narodził się Syn Boga Ojca"20. Tymczasem Mesjasz nie jest przecież Synem trzeciej osoby Trójcy Świętej, tak jak jest Synem dziewicy Maryi. Chrystus nie narodził się z Ducha Świętego jak z ojca. Z Maryi natomiast zrodził się jak z matki ${ }^{21}$. Ildefons tłumaczy, że dzięki wyjątkowej łasce Bożej człowiek u początku istnienia swej natury ,połączył się ze Słowem Bożym w tak wielką jedność, że ten sam Syn Boży jest Synem Człowieczym, a Syn Człowieczy jest Synem Bożym"22. Jednocześnie zwraca uwagę, że w akcie wcielenia dzięki Duchowi Świętemu, który nazywany jest też „Bożym Darem”, człowiek może doświadczyć pokory samego Boga. On bowiem w „łonie Dziewicy raczył przyjąć całego człowieka, czyli ciało, duszę i ducha, zamieszkując nienaruszone matczyne ciało i niena-

19 Ildefonsus Toletanus, De cognitione baptismi XLI, CCL 114 A, s. 377, POK 33, s. 75.

20 Ildefonsus Toletanus, De cognitione baptismi XLIII, CCL 114 A, s. 378, POK 33, s. 77.

21 Por. Ildefonsus Toletanus, De cognitione baptismi XLII.

22 Ildefonsus Toletanus, De cognitione baptismi XLIII, POK 33, s. 77. Najpełniej prawda ta została wyjaśniona w dziele De virginitate Sanctae Mariae 628-635: „Wszystkie proroctwa były dane, że z Ducha Świętego i z Maryi zawsze Dziewicy Słowo stanie się ciałem, że Bóg stanie się człowiekiem, że stanie się ludzkim to, co było Boże, nie przez zmniejszenie się boskości, nie przez ustanie wieczności, nie przez zmianę niezmiennej prawdy, lecz przez przyjęcie ciała, przez uczestnictwo człowieka, przez współuczestnictwo ludzkości. I tak w jedności Osoby tym samym jest Słowo będące ciałem, tym samym jest człowiek będący Bogiem, tym samym jest będący Bóstwem i człowieczeństwem" (CCL 114A, s. 190, tł. W. Kania, Ildefons z Toledo, O wieczystym dziewictwie Najświętszej Maryi Panny, w: Ojcowie Kościoła łacińscy. Teksty o Matce Bożej, Niepokalanów 1981, s. 178). 
ruszone opuszczając"23. Wymienienie w akcie wcielenia działania tylko Ducha Świętego, a więc jednej osoby Trójcy Świętej, nie zmienia faktu, że Trójca Święta działa zawsze nierozdzielnie. Tak więc „,kiedy w dokonywaniu jakiegoś dzieła wspomniana jest jedna z trzech Osób, uznajemy - uczy biskup Toledo - że działa cała Trójca"24.

Ildefons wspomina również obecność Ducha Świętego w czasie nawiedzenia Elżbiety przez Maryję. Elżbieta napełniona trzecią osobą Trójcy Świętej wypowiedziała, zapisane przez św. Łukasza, pełne wiary w dzieła Boże pozdrowienie Maryi. Duch Święty był obecny również w życiu Symeona i Anny. I to z Jego natchnienia Symeon wypowiedział proroctwo na temat zbawczej misji Chrystusa, która obejmie cały świat ${ }^{25}$.

\section{Rola Ducha Świętego w życiu ucznia Jezusa}

Zgodnie ze swoją obietnicą Jezus po wstąpieniu do nieba zesłał na Apostołów Ducha Świętego (por. Dz 2,2-4). On, który w swej naturze jest prawdziwym Bogiem, dla ludzi wszystkich czasów pozostaje Darem ${ }^{26}$. Jest bowiem tym, który rozdziela wybranym przez siebie ludziom odpowiednie dla nich łaski. Wyraźnie wskazuje na to opis zesłania Ducha Świętego na apostołów. Święty Łukasz zapisał: „Ukazały się im też języki jakby z ognia, które się rozdzieliły, i na każdym z nich spoczął jeden” (Dz 2,3). Zatem Duch nie został podzielony pomiędzy apostołów, ale na

23 Ildefonsus Toletanus, De cognitione baptismi XLIII, POK 33, s. 78. Mówiąc o pełni człowieczeństwa Chrystusa (ciało, dusza, duch), Ildefons za św. Augustynem (De fide et symbolo 4, 8) przeciwstawia się doktrynie apolinaryzmu i jednocześnie wyznaje wiarę w dziewictwo Maryi. Por. także: Ildefonsus Toletanus, De virginitate Sanctae Mariae 3.

24 Ildefonsus Toletanus, De cognitione baptismi XLI, CCL 114 A, s. 377-378, POK 33, s. 76.

25 Por. Ildefonsus Toletanus, De virginitate Sanctae Mariae 1080-1090.

26 Prawdę o Duchu Świętym jako darze dla Kościoła obszernie przedstawił w swojej twórczości św. Ireneusz z Lyonu. Por. B. Częsz, Duch Święty został nam dany. Nauczanie Ojców i wiara starożytnego Kościoła, Gniezno 1998, s. 15-17. 
każdym z nich spoczął w całej pełni. W tej chwili otrzymali oni łaskę rozumienia wszystkich języków ${ }^{27}$. Dzięki temu darowi mogli głosić Dobrą Nowinę wszystkim zebranym ludziom, niezależnie od ich pochodzenia i języka. A potem, mając się rozejść z misją głoszenia Ewangelii po całym świecie, postanowili dla trwania w jedności wiary ustalić wspólne punkty nauczania, czyli symbol wiary. Biskup Toledo głosi ten pogląd, idąc za tradycyjnym nauczaniem wcześniejszych ojców: Ambrożego z Mediolanu czy Rufina z Akwilei ${ }^{28}$. Tak więc jego zdaniem apostołowie „przebywając razem, napełnieni Duchem Świętym, uzgodnili to krótkie świadectwo przepowiadania w swym gronie, aby każdy z nich zrozumiał. Ułożyli je zatem dla siebie i postanowili przekazać wierzącym jako regułę wiary" 29 .

Szczególnym sakramentem, w którym działa trzecia osoba Trójcy Przenajświętszej, jest chrzest, w którym człowiek umiera i rodzi się na nowo. Ildefons mówi tu o płodności Ducha Świętego. Z Niego bowiem rodzą się nowi członkowie Kościoła ${ }^{30}$. W tym sakramencie człowiek zostaje opieczętowany przez Ducha Świętego ${ }^{31}$. Biskup Toledo podkreśla, że jedynym szafarzem sakramentów jest Jezus Chrystus ${ }^{32}$. To On udziela chrztu zewnętrznie i wewnętrznie, tzn. obmywa wodą i wylewa na katechumena Ducha Świętego. Powołując się na słowo Jezusa „«Jeśli ktoś jest spragniony, a wierzy we Mnie - niech przyjdzie do Mnie i pije! Jak

27 Por. Ildefonsus Toletanus, De cognitione baptismi LXVIII. Por. także: Isidorus Hispalensis, Etymologiae 7, 3, 23-26.

28 Por. Ambrosius Mediolanensis, Explanatio Symboli 3, 8; Rufinus Aquileiensis, Explanatio Symboli 2; T. Kaczmarek, Wyznania wiary starożytnego Kościoła, „Studia Włocławskie" 9 (2006) s. 99-100.

29 Ildefonsus Toletanus, De cognitione baptismi XXXIII, CCL 114 A, s. 373, POK 33, s. 68 .

30 Por. Ildefonsus Toletanus, De itinerare deserti XIX.

31 Por. Ildefonsus Toletanus, De cognitione baptismi LXVI.

32 Ildefons jest przekonany, że chrzest udzielony w imię Trójcy Świętej jest ważny niezależnie od godności szafarza. Por. P. Wygralak, Przygotowanie do chrztu Hiszpanii Wizygockiej. Wskazania Ildefonsa z Toledo, w: Ildefons z Toledo, Pouczenie o chrzcie, POK 33, Poznań 2018, s. 27. 
rzekło Pismo: Strumienie wody żywej popłyną z jego wnętrza». A powiedział to o Duchu, którego mieli otrzymać wierzący w Niego" (J 7,37-39), wnioskuje, że trzecia osoba Trójcy Świętej nazwana jest w Ewangelii „wodą”. Rodzi się jednak pytanie, która woda oznacza Bożego Ducha? Otóż zdaniem Ildefonsa możemy mówić o dwóch rodzajach wody, tej widzialnej, a więc wodzie sakramentalnej, do której wchodzi katechumen w czasie liturgii chrztu, oraz o wodzie niewidzialnej - ,wodzie Ducha”. Należy widzieć w niej działanie Ducha Świętego, który oczyszcza duszę i ją karmi ${ }^{33}$. Duch Święty otrzymany we chrzcie będzie odtąd uczył człowieka życia wiarą oraz postępowania zgodnego z moralnością chrześcijańską ${ }^{34}$. Ponadto dzięki przyjęciu Go w sakramencie odrodzenia ochrzczony poznaje tajemnice wyznawanej wiary. Ildefons nawiązuje tu do zapisu Apokalipsy (Ap 5,5) o księdze świętej władzy, zamkniętej dla zachowania tajemnicy na siedem pieczęci. Owocem przyjętego chrztu jest otwarcie księgi Pisma Świętego, w której zostało zapisane objawienie przekazane człowiekowi przez Chrystusa. On ukazał ludziom znaczenie słów Biblii, sam zaś wypełnił wszystko, co było konieczne dla zbawienia rodzaju ludzkiego. W ten sposób złamał owych siedem pieczęci, a więc urzeczywistnił to, co one symbolizowały: wcielenie, narodzenie, mękę, śmierć, zmartwychwstanie, chwałę i królestwo. Ildefons uczy: „Ich [pieczęci] złamanie oznacza pełne odkupienie rodzaju ludzkiego"35.

Ważnym obrzędem w liturgii chrztu jest namaszczenie olejem. Ildefons, wskazując na jego znaczenie, przypomina namaszczenie Chrystusa olejkiem radości, czyli Duchem Świętym. Mając na uwadze to wydarzenie, a także powołując się na słowa św. Jana zapisane w jego pierwszym liście (1J 2,20.27), można powiedzieć, że Duch Święty jest olejem namaszczenia. Katechumen zostaje zatem namaszczony Duchem Świętym. Od tej chwili, zgodnie z myślą apostoła, trwa już w nim otrzy-

\footnotetext{
33 Por. Ildefonsus Toletanus, De cognitione baptismi LXX.

34 Por. Ildefonsus Toletanus, De cognitione baptismi XVI.

35 Ildefonsus Toletanus, De cognitione baptismi XIX, CCL 114 A, s. 364, POK 33, s. 55.
} 
mane namaszczenie, czyli Duch Święty, i nie potrzebuje on żadnego ,pouczenia od nikogo, ponieważ Jego namaszczenie poucza [...] o wszystkim" (1J 2,27) ${ }^{36}$. Jest więc Duch Święty dla chrześcijanina źródłem wiedzy we wszystkich sprawach wiary.

W Biblii Duch Święty przedstawiany jest jako gołębica, którą cechuje prostota, niewinność, brak gniewu. Człowiek ochrzczony, zgodnie z zachętą Pana Jezusa „Bądźcie nieskazitelni jak gołębice” (Mt 10,16), ma dzięki otrzymanemu Duchowi Świętemu postępować tak, jak czyni to gołębica, tzn. trwać w prostocie, niewinności i miłości ${ }^{37}$.

Jest też Duch Święty niezastąpionym wsparciem w głoszeniu Ewangelii. Według biskupa Toledo wynika to nie tylko z faktu posłania trzeciej osoby Trójcy Przenajświętszej przez Zmartwychwstałego, ale z obietnicy Mesjasza, który zapewniał swoich uczniów, że w chwili prześladowań to Duch Święty będzie im podpowiadał, co mają mówić. Jeśli zatem jest On dany uczniom Jezusa w chwili prześladowań, to dlaczego nie miałby ,przemawiać przez ludzi, którzy głoszą Chrystusa szukającym wiedzy o Nim?"38. Ildefons jest przekonany, że przez usta proroków Starego Testamentu, apostołów, głosicieli Ewangelii zawsze przemawiał Duch Święty ${ }^{39}$. Prawda o nauczaniu, w którym fundamentalną rolę odgrywa Duch Święty, wynika również z imienia Paraklet, którym się Go określa. Imię to według nauczania Ildefonsa oznacza bowiem w języku łacińskim nie tylko 'pocieszyciela', ale także 'mówcę' lub 'obrońcę $^{40}$. Jeśli natomiast chodzi o pierwsze znaczenie imienia Paraklet, jako 'Pocieszyciel', to wiąże się ono z posłaniem przez Chrystusa, który wstąpił do nieba, Ducha Świętego do płaczących apostołów. W ten sposób

\footnotetext{
36 Por. Ildefonsus Toletanus, De cognitione baptismi LXXI.

37 Por. Ildefonsus Toletanus, De cognitione baptismi LXVII.

38 Ildefonsus Toletanus, De cognitione baptismi XVII, CCL 114 A, s. 362, POK
} 33, s. 52.

39 Por. Ildefonsus Toletanus, De cognitione baptismi LXXVII; Ildefonsus Toletanus, De virginitate Sanctae Mariae 140.

40 Por. Ildefonsus Toletanus, De cognitione baptismi LXI. 
wypełnia się jedno z Jezusowych błogosławieństw: „Błogosławieni płaczący, albowiem oni zostaną pocieszeni” (Mt 5,4) ${ }^{41}$.

Ildefons wspomina również o geście nałożenia rąk, którego skutkiem jest zstąpienie na człowieka Ducha Świętego i Jego uświecającej mocy ${ }^{42}$. Praktyka ta jest znana od czasów apostolskich, co poświadcza św. Łukasz w Dziejach Apostolskich, gdy mówi o nałożeniu rąk przez Pawła na uczniów w Efezie (Dz 19,6), a także przez Piotra i Jana w Samarii (Dz 8,17). Owocem nałożenia rąk było zstąpienie Ducha Świętego i obdarowanie uczniów darem języków oraz darem proroctwa ${ }^{43}$. Biskup Toledo podkreśla jednak, że aby On zstąpił, potrzeba wezwać „,szczodrego Szafarza tego daru”. Sam człowiek nie ma bowiem władzy, aby udzielić Ducha Świętego ${ }^{44}$. Ponadto nawiązując do ognia jako symbolu zstępującego Ducha Świętego, Ildefons wskazuje, że dokonuje On jak gdyby wypalenia wnętrza człowieka. Należy to rozumieć jako wewnętrzne oczyszczenie, spalenie wszelkich grzechów zalegających w duszy człowieka ${ }^{45}$. W liturgii sakramentów wtajemniczenia istotną rolę ogrywa również namaszczenie krzyżmem, czego skutkiem jest przeniknięcie człowieka mocą Ducha Świętego. Dzięki temu, jak zauważa biskup Toledo, dusza człowieka jest zdolna do poznania Boga i miłowania Go ${ }^{46}$. Wiernym, którzy są tego godni, Duch Święty ofiaruje swoje dary. Ildefons wymienia siedem darów trzeciej osoby Trójcy Świętej: mądrości, rozumu, rady, męstwa, wiedzy, pobożności, bojaźni Bożej ${ }^{47}$.

${ }^{41}$ Por. Ildefonsus Toletanus, De cognitione baptismi LXI.

42 Por. Ildefonsus Toletanus, De cognitione baptismi CXXXI.

43 Por. Ildefonsus Toletanus, De cognitione baptismi CXXXII. Por. także: Isidorus Hispalensis, De ecclesiasticis officiis 2, 27, 1-2.

44 Por. Ildefonsus Toletanus, De cognitione baptismi CXXXIII.

45 Prawda o przyjmowaniu Ducha Świętego w Eucharystii była komentowana przez św. Efrema. Sięgając do obrazu ognia, który zesłany z nieba strawił ofiarę Eliasza, Efrem uczył, że podobnie Duch Święty przyjmowany w Eucharystii spala grzechy i uświęca człowieka. Por. Częsz, Duch Święty został nam dany, s. 47.

46 Por. Ildefonsus Toletanus, De cognitione baptismi CXXVII.

47 Por. Ildefonsus Toletanus, De cognitione baptismi LXII. 
Biskup Toledo zwraca również uwagę na rolę Ducha Świętego jako tego, który natchnął proroków Starego Testamentu, a także autorów Ewangelii i apostołów. A zatem bez żadnej wątpliwości można powiedzieć, że księgi Pisma Świętego nie są zwykłymi księgami, ale są natchnione przez Ducha Świętego, co wyraził sam św. Paweł w Liście do Tymoteusza $(2 \mathrm{Tm} 3,16)$. Jako takie stanowią więc one wielkie dobro Kościoła i służą do nauczania. Biskup Toledo, sięgając do spisu sporządzonego wcześniej przez św. Augustyna ${ }^{48}$, wymienia po kolei wszystkie księgi Starego i Nowego Testamentu, które zgodnie z tradycją przekazaną przez ojców uważa się za natchnione, a więc stanowiące kanon ${ }^{49}$. Wierni powinni szukać w księgach Pisma Świętego woli Boga, czytać je i zapamiętywać, „nawet jeśli nie prowadzi to jeszcze do ich zrozumienia"

\section{Podsumowanie}

Nauczanie Ildefonsa z Toledo o Duchu Świętym ma charakter ściśle katechetyczny. Biskupowi zależało, aby duszpasterze przygotowali katechezy, które w pierwszym rzędzie podkreślałyby główne prawdy wiary. To dlatego w sposób wyraźny, bez wchodzenia w zawiłe rozważania teologiczne, podejmuje temat prawdziwego bóstwa Ducha Świętego oraz równości wszystkich osób Trójcy Świętej. Omawia też Jego rolę w dziele zbawienia, zatrzymując się przede wszystkim nad prawdą o wcieleniu Bożego Syna. Najwięcej miejsca, co zrozumiałe, poświęca Ildefons znaczeniu Ducha Świętego w życiu chrześcijanina. Przekonuje, że to On poucza wiernych, On umacnia w głoszeniu Ewangelii, On przychodzi w Eucharystii i oczyszcza człowieka z grzechów, On uzdalnia człowieka

48 Por. Augustinus Hipponensis, De doctrina christiana II 9, 13.

49 Por. Ildefonsus Toletanus, De cognitione baptismi LXXIX.

50 Ildefonsus Toletanus, De cognitione baptismi LXXX, CCL 114 A, s. 394, POK 33, s. 100. 
do miłowania Boga i bliźniego, On też natchnął autorów Pisma Świętego, w którym wierni powinni szukać woli Boga.

Treść nauczania Ildefonsa nie jest w pełni oryginalna, jako że została opracowana częściowo na podstawie dzieł Augustyna z Hippony i Izydora z Sewilli. Tym niemniej forma wypowiedzi, przejrzystość wykładu stanowią o wartości dzieła i jego duszpasterskiej przydatności.

\section{The Holy Spirit in the Teaching of Saint Ildefonsus of Toledo}

(summary)

The article presents the teaching of St. Ildefonsus of Toledo on the Holy Spirit especially that contained in his writings devoted to the sacrament of baptism. On the basis of selected passages from the Holy Scripture and the reflections of earlier authors, the Bishop of Toledo emphasizes the truth of the divinity of the Holy Spirit and His equality with the Father and the Son. He also discusses the role of the Holy Spirit in the work of salvation, drawing particular attention to the act of the Incarnation of the Son of God. However, he decidedly gives most of his space to the role of the Holy Spirit in the life of every Christian. The Holy Spirit is the one who bestows the necessary grace, enables man to love God and neighbour, supports him in deepening his knowledge of the mysteries of faith, strengthens and gives wisdom in the work of evangelization. In his teachings, Ildefonsus uses the legacy of the earlier Church Fathers, above all Augustine and Isidore of Seville. But he remains original in the form of presenting difficult truths of the faith. His language is accessible, vivid and at the same time precise.

Keywords: Holy Spirit; Ildefonsus of Toledo; baptism; Incarnation; catechesis

\section{Duch Święty w nauczaniu św. Ildefonsa z Toledo}

(streszczenie)

W artykule przedstawiono nauczanie Ildefonsa z Toledo o Duchu Świętym zawarte przede wszystkim w jego pismach poświęconych sakramentowi chrztu. Biskup Toledo na podstawie wybranych tekstów Pisma Świętego, jak również przemyśleń wcześniejszych autorów podkreśla prawdę o bóstwie Ducha Świętego oraz Jego równości z Ojcem i Synem. Omawia również Jego rolę w dziele zbawienia, zwracając przede wszystkim uwagę na akt wcielenia Bożego Syna. Zdecydowanie najwięcej miejsca poświęca jednak ukazaniu roli Ducha Świętego w życiu każdego chrześcijanina. To On obdarza potrzebnymi łaskami, uzdalnia człowieka do miłowania Boga i bliźniego, wspiera go w zgłębianiu tajemnic wiary, umacnia i obdarza mądrością w dziele ewangelizacji. W swoim nauczaniu Ildefons korzysta z dorobku wcześniejszych ojców Kościoła, przede wszystkim Augustyna i Izydora 
z Sewilli. Pozostaje natomiast oryginalny w formie przedstawienia niełatwych prawd wiary. Jego język jest przystępny, obrazowy, a jednocześnie precyzyjny.

Słowa klucze: Duch Święty; Ildefons z Toledo; chrzest; wcielenie; katecheza

\section{Bibliografia \\ Źródla}

Ambrosius Mediolanensis, Explanatio Symboli, ed. B. Botte, SCH 25bis, Paris 1961, tł. L. Gładyszewski, Ambroży z Mediolanu, Wyjaśnienie Symbolu, Kraków 2004, s. $45-50$.

Augustinus Hipponensis, De doctrina christiana, ed. K.D. Daur - J. Saint-Martin, CCL 32, Turnhout 1962, tł. J. Sulowski, Augustyn, O nauce chrześcijańskiej, Warszawa 1989.

Augustinus Hipponensis, De fide et symbolo, ed. R. Vander Plaetse, CCL 46, Turnhout 1968, tł. L. Gładyszewski, Augustyn, O wierze i symbolu, w: Symbol Apostolski w nauczaniu ojców, tł. L. Gładyszewski, Kraków 2010, s. 16-59.

Ildefonsus Toletanus, De cognitione baptismi, ed. V. Yarza Urquiola, CCL 114 A, Turnhout 2007, s. 343-435, tł. A. Strzelecka, Ildefons z Toledo, Pouczenie o chrzcie, POK 33, Poznań 2018, s. 35-164.

Ildefonsus Toletanus, De itinere baptismi, ed. V. Yarza Urquiola, CCL 114 A, Turnhout 2007, s. 436-471.

Ildefonsus Toletanus, De virginitate Sanctae Mariae, ed. V. Yarza Urquiola, CCL 114 A, Turnhout 2007, s. 145-273, tł. W. Kania, Ildefons z Toledo, $O$ wieczystym dziewictwie Najświętszej Maryi Panny, w: Ojcowie Kościoła łacińscy. Teksty o Matce Bożej, Niepokalanów 1981, s. 161-201.

Isidorus Hispalensis, De ecclesiasticis officiis, ed. A.C. Lawson, CCL 113, Turnhout 1989.

Isidorus Hispalensis, Etymologiarum sive Originum libri XX, PL 82, 73-728.

Rufinus Aquileiensis, Explanatio Symboli, ed. M. Simonetti, CCL 20, Turnhout 1961.

\section{Opracowania}

Częsz B., Duch Święty został nam dany. Nauczanie Ojców i wiara starożytnego Kościoła, Gniezno 1998. 
Díaz y Díaz M.C., La obra literaria de los obispos visigóticos toledanos: Supuestos y circunstancias, en: La patrología toledano-visigoda, XXVII Semana Española de Teología (Toledo, sept. 1967), Madrid 1970, s. 45-63.

Hormaeche Basauri J.M., La pastoral de la iniciación cristiana en la España visigoda: estudio sobre „De cognitione baptismi” de San Ildefons de Toledo, Toledo 1983.

Huidobro F., San Ildefonso de Toledo, „Teología y Vida” 23 (1982) s. 191-202.

Kaczmarek T., Wyznania wiary starożytnego Kościoła, „Studia Włocławskie” 9 (2006) s. 93-107.

Ledesma J.P., El „,De Itinere Deserti” de San Ildefonso de Toledo, Toledo 2005.

Yarza Urquiola V., Introdución y estudio, w: Ildefonsi Toletani Episcopi, De virginitate sanctae Mariae, De cognitione baptismi, De itinere deserti, CCL 114 A, Turnhout 2007, s. 275-342.

Wygralak P., Przygotowanie do chrztu Hiszpanii Wizygockiej. Wskazania Ildefonsa z Toledo, w: Ildefons z Toledo, Pouczenie o chrzcie, POK 33, Poznań 2018, s. 7-33. 